College of Vet. Medicine, University of Dohuk/ Iraq

\title{
THE EFFECT OF SUBCLINICAL EXPERIMENTAL INFECTION WITH HAEMONCHUS CONTORTUS ON CHEMICAL COMPOSITION OF CARCASS OF KARADI LAMBS
}

(With One Table and 4 Figures)

By

\author{
NADHIM S. ABDULAZIZ JAKHSI \\ and ADNAN M. ABDULLAH REKANI*
}

*Department of Animal Production, University of Dohuk/ Iraq

(Received at 12/12/2006)

Haemonchus contortus تأثير الإصابة التجريبي دون السريري بليدان على التركيب الكيميائي لذبيحة الحملان الكرادي ناظم سليمان عبل العزيز الجقسي ، عدنان عبد الله الريكانسي

أجريت هذه الدراسة لمعرفة مدى تأثير الإصابة التجريبي دون ألسريري لديدان Haemonchus contortus

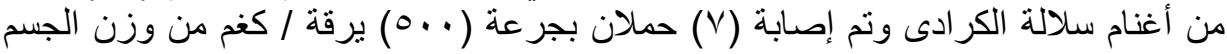

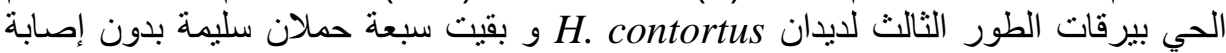

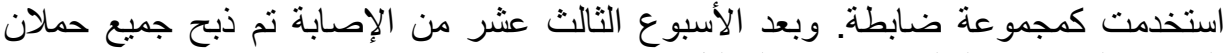

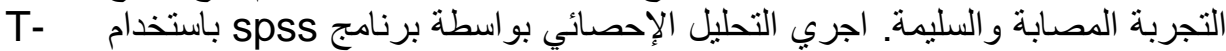

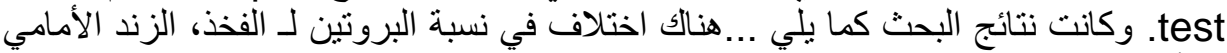

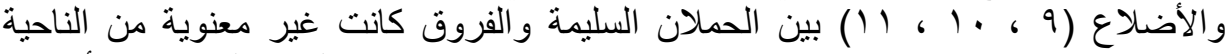

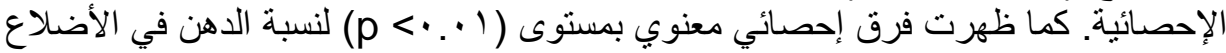

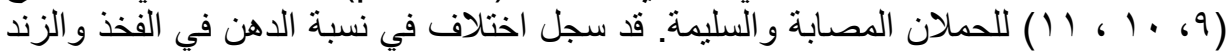

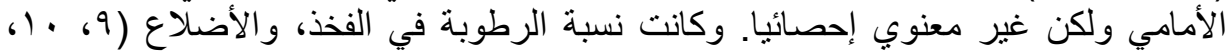

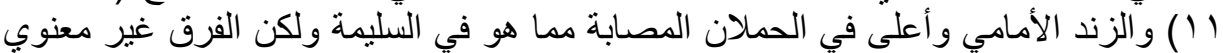

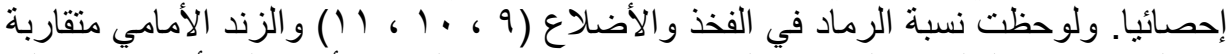

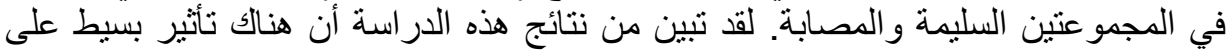
H. contortus التركيب الكيميائى للأبيحة عند اصابة الحملان الكردى بطفيل

\section{SUMMARY}

The present study was conducted to investigate the effect of subclinical infection with Haemonchus contortus on meat composition of Karadi lambs. A total of 14 lambs were used in this study; seven lambs were infected with (500) infective larvae of Haemonchus contortus larvae $\mathrm{kg}^{-1}$ 
body weight, the remained lambs were left as uninfected control group. This study continued until $13^{\text {th }}$ week post-infection. Statistically analyzed by SPSS program using T-test the results indicated that there was differences in protein percentage in leg, ribs $(9,10,11)$ and fore shank between the two groups (infected and control). These differences were statistically not significant. There was significant difference $(\mathrm{p}<$ 0.01) of fat percentage in ribs $(9,10,11)$ area between the two groups, while there was slight difference in fat percentage in leg and fore shank areas but statistically not significant. The moisture percentage in leg, ribs $(9,10,11)$ and fore shank areas of infected group was higher than the control group but this difference was statistically not significant. Ash percentage in leg, ribs $(9,10,11)$ and fore shank areas was convergent of both groups. In this study it can be concluded that there was a slight effect of subclinical infection with $H$. contortus on chemical composition of Karabi lambs carcasses.

Key words: Haemonchus contortus, chemical composition of carcass, karadi lambs

\section{INTRODUCTION}

Haemonchus Contortus is a blood-sucking parasite that pierces the lining of the abomasum, causing blood plasma and proteins loss of the host. The pathogenic effects of $H$. contortus resulted from the inability of the host to compensate for the blood loss (Bowman and Lynn, 1999). In addition to mortality the major losses are attributed to reduced feed efficiency, slow rate of gain, poor reproduction efficiency, lowered production of wool and meat, and labor and drugs associated with control (Hartwig, 2000).

$H$. contortus is one of the most important parasite in Iraq because it is highly prevalent and pathogenically severe. This has been confirmed by the parasitological survey (Kadhim, 1972) and epidemiological studies (Al-Saqur et al., 1984; Issa et al., 1984). The sheep were subjected to various gastrointestinal nematodes infection among other ruminants livestock. The lambs were most susceptible to parasitic diseases because the innate and acquired resistance is poor. The researches showed that the lambs were most susceptible and effective to infection than adult animals (Soulsby, 1982). Early weaned lambs from infected ewes with $H$. contortus were characterized by weakness and frailness either due to their infection by worms from their dams or to reduction of milk productivity of ewes (Donald and Waller, 1973 and Thomas and Ali, 1983). 
The Karadi sheep are the most breed which are reared in Kurdistan region (north of Iraq), that are characterized by high milk, wool production and the rapid growth of lambs (Ghazal \& Alsaeegh, 1980)

The aim of this study was to determine the effect of subclinical experimental infection with $H$. contortus on chemical composition of carcass of Karadi lambs.

\section{MATERIALS and METHODS}

Fourteen (5-7) month-old-Karadi-lambs obtained from native Rodeo, which were reared in a parasite-free condition, faecal samples of all lambs were examined by floatation, sedimentation and Baermann technique for assurance that were free from endoparasites. All lambs were treated with anthelmintic to remove their existing worm burdens prior to experimental infection according to weight.

The experiment was carried out in animal breeding project at the Animal Production Department/ University of Dohuk. The lambs were divided equally into two groups according to the body weight. The first group was considered as a control and remained uninfected until to the end of the study. The second group was drenched with 500 Haemonchus contortus larvae (L3) $\mathrm{kg}^{-1}$ body weight. The third stage larvae L3 were prepared by method of Theodorides (1964). The infection continued until 13th week post-infection. Faecal samples were collected weekly direct from the rectum of each lamb and the number of worm egg count was estimated by using the modified McMaster technique (Gordon and Whitlock, 1939). At the end of the experiment, lambs were slaughtered. After $24 \mathrm{~h}$ chilling, the cold carcasses were dissected into commercial cuts. Muscle and adipose tissue, including subcutaneous fat for leg, fore shank and three ribs area $(9,10 \& 11)$, were blended together and hashed in a small feed processor, thereafter preserved in nylon bag and freezing at $\left(-20{ }^{\circ} \mathrm{C}\right)$ until the chemical analysis execution. Meat moisture was determined by using electrical hot air - oven at $105{ }^{\circ} \mathrm{C}$ for $8 \mathrm{hrs}$ until fixed weight.

Ash was determined by using Muffle furnace at $550{ }^{\circ} \mathrm{C}$. for $6 \mathrm{hrs}$ until the color of ash became whitish grey.

Protein was determined by using kjeldahl method. Crude fat was determined by mean fat extracting from dry sample by using anhydrous ethyl ether (A.O.A.C., 1980).

\section{RESULTS}


The results of subclinical effect of $H$. contortus on chemical composition of protein, fat, ash and moisture from the leg and three ribs $(9,10,11)$ and fore shank area for the control and infected lambs carcasses are shown in Table (1). Protein percentage in leg, three ribs (9, $10,11)$ and fore shank areas of control group was higher than that of the infected lambs as shown in Figure (1). But the difference between the two groups was not statistically significant.

Table 1: The mean of chemical composition (protein, fat, ash and moisture) from the leg and three ribs $(9,10,11)$ and fore shank areas for the control and infected carcass lambs.

\begin{tabular}{|c|c|c|c|c|c|}
\hline & Groups & Protein $\%$ & Fat \% & Ash \% & Moisture \% \\
\hline \multirow{2}{*}{ Ribs area } & Control & $\begin{array}{r}15.712 \\
\pm 0.043\end{array}$ & $\begin{array}{l}25.015 \text { * } \\
\pm 0.485\end{array}$ & $\begin{array}{c}0.982 \\
\pm 0.043\end{array}$ & $\begin{array}{c}57.868 \\
\pm 0.653 \\
\end{array}$ \\
\hline & Infected & $\begin{array}{r}15.418 \\
\pm 0.331 \\
\end{array}$ & $\begin{array}{l}24.442 * \\
\pm 0.485 \\
\end{array}$ & $\begin{array}{c}0.987 \\
\pm 0.027 \\
\end{array}$ & $\begin{array}{r}58.570 \\
\pm 0.692 \\
\end{array}$ \\
\hline \multirow[b]{2}{*}{ Leg area } & Control & $\begin{array}{c}15.350 \\
\pm 0.414\end{array}$ & $\begin{array}{l}22.250 \\
\pm 1.213\end{array}$ & $\begin{array}{c}1.018 \\
\pm 0.032\end{array}$ & $\begin{array}{c}60.991 \\
\pm 1.269\end{array}$ \\
\hline & Infected & $\begin{array}{r}15.147 \\
\pm 0.417 \\
\end{array}$ & $\begin{array}{r}21.165 \\
\pm 1.418 \\
\end{array}$ & $\begin{array}{c}0.997 \\
\pm 0.022 \\
\end{array}$ & $\begin{array}{r}62.152 \\
\pm 1.506 \\
\end{array}$ \\
\hline \multirow{2}{*}{$\begin{array}{l}\text { Fore } \\
\text { shank } \\
\text { Area }\end{array}$} & Control & $\begin{array}{r}19.750 \\
\pm 0.601\end{array}$ & $\begin{array}{c}6.691 \\
\pm 1.020\end{array}$ & $\begin{array}{c}1.024 \\
\pm 0.025\end{array}$ & $\begin{array}{r}72.217 \\
\pm 1.505\end{array}$ \\
\hline & Infected & $\begin{array}{c}19.635 \\
\pm 0.560\end{array}$ & $\begin{array}{c}5.954 \\
\pm 0.828 \\
\end{array}$ & $\begin{array}{c}1.014 \\
\pm 0.023 \\
\end{array}$ & $\begin{array}{r}73.087 \\
\pm 1.219 \\
\end{array}$ \\
\hline
\end{tabular}

* significant differences $(\mathrm{P}<0.01)$.

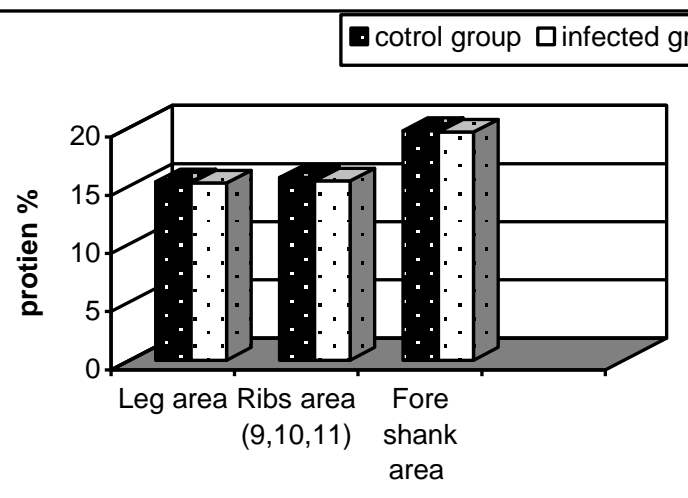

(Carcass cuts)

Fig. 1: Mean of protein percentage in leg, $\operatorname{Ribs}(9,10,11)$ and fore shank areas of carcasses from control and infected lambs. 
Fat percentage in leg, three ribs $(9,10,11)$ and fore shank areas of control and infected group are shown in Figure (2). There was significant differences $(\mathrm{P}<0.01)$ in fat percentage between the two groups (control and infected lambs) in three ribs $(9,10,11)$ area. While, there was difference in leg and fore shank areas, but statistically non significant.

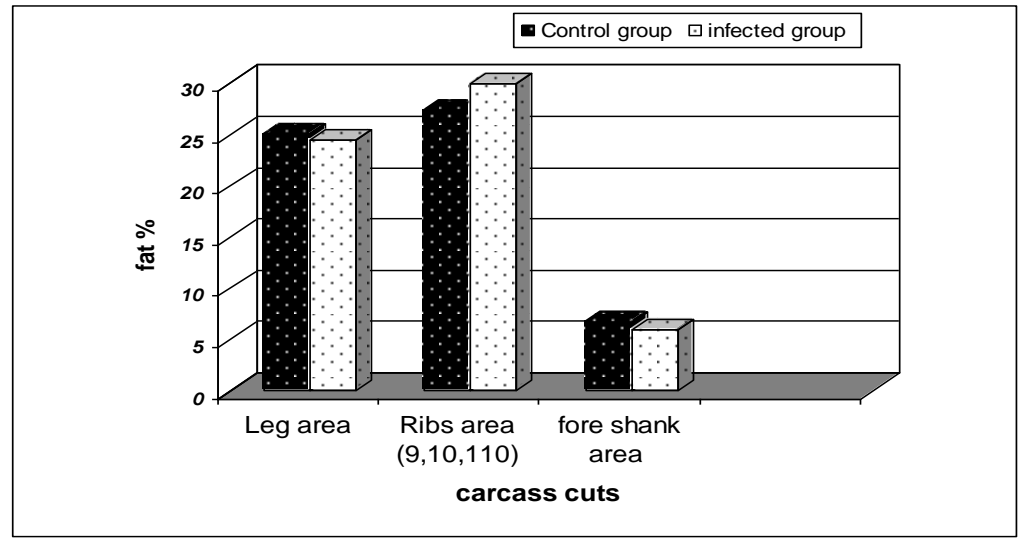

Fig. 2: Mean of fat percentage in leg, ribs $(9,10,11)$ and fore shank areas of carcasses from control and infected lambs

Ash percentage in leg, three ribs $(9,10,11)$ and fore shank area of control and infected group are shown in Figure (3). The ash percentage of both groups (infected and control) was convergent in leg, three ribs $(9,10,11)$ and fore shank areas and there was not significant difference between the two groups.

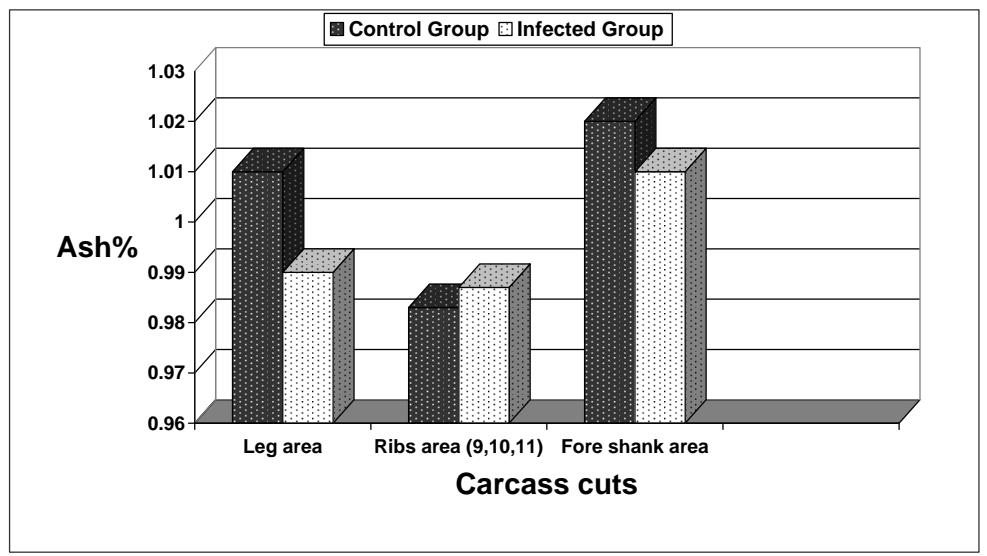

Fig. 3: Mean of ash percentage in leg, Ribs $(9,1,11)$ and fore shank areas of carcasses from control and infected lambs 
The moisture percentage in leg, ribs $(9,10,11)$ and fore shank of infected lambs was higher than the control group as shown in Figure (4). This differences were statistically not significant.

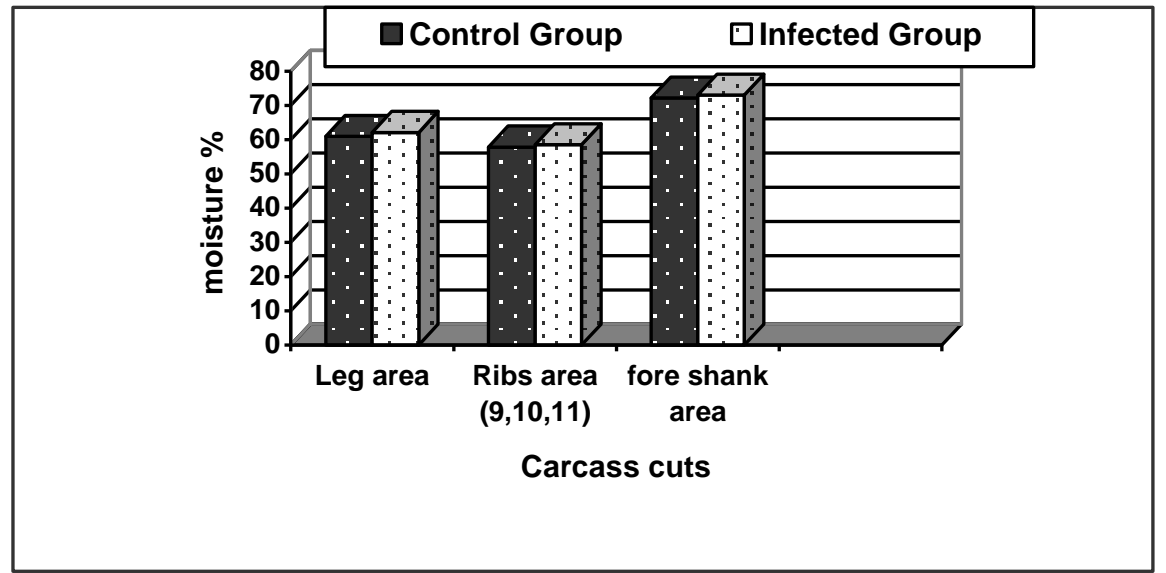

Fig. 4: Mean of moisture percentage in leg, Ribs $(9,10,1)$ and fore shank areas of carcasses from control and infected lambs

\section{DISCUSSION}

There are very few workers who study the effect of gastrointestinal parasites on body composition and carcass quality as well as quantity. In the present study there was sub-clinical effect of Haemonchus contortus on chemical composition of the carcass, such as protein, fat, and moisture of legs, three ribs and fore shank.

There were differences between infected and control lambs as illustrated in Table (1) and Figure (1, 2, 3 and 4). This effect related to depression of weight gain and growth rate of infected lambs, major losses are attributed to reduced feed efficiency, slow of rate gain, poor reproduction efficiency, lowered production of meat of infected lambs (Hartwig, 2000).

Coop (1979) suggested that this depression in weight gain was due to reduction in food intake reducing the overall availability of nutrients for metabolic processes in addition to decrease in the efficiency of utilization of food components, especially energy and protein. Albers et al. (1984) recorded a drop in weight of Merino lambs infected with L3 larvae of H.contortus. Pralomkarn et al. (1997) demonstrated lower weight gain of the infected kids with $H$. contortus compared with uninfected group $(\mathrm{p}<0.05)$. 
Anorexia is a common feature to most gastrointestinal parasite disease (Asghar, 1982). The physiological changes in the alimentary tract associated with parasitism may lead to the inefficient use of available nutrients for growth, (Sykes and Coop, 1977). In addition, due to the blood sucking activities by $4^{\text {th }}$ stage larvae and adult worms, when each worm removes about $0.05 \mathrm{ml}$ of blood per day from the infected sheep with $H$. contortus (Urquhart et al., 1996) also cause hypoproteinemia that resulting from blood losses.

Coop, et al. (1985) observed a reduction of mean protein depositon in the infected lambs with Ostertagia circumcincta about $34 \%-52 \%$ in comparison with control group. Ali (1981) found a significant difference $(\mathrm{P}<0.01)$ in the carcass weight between the infected and control lambs. Al-Jakhsi (1986) reported that the carcass quality, Longsimus dorsi muscle (LD), fat thickness, carcass weight and meat fat and bone ratio were observed to be affected slightly in infected groups than the control and were more obvious in Awassi breed than in Bulgarain breed. Garrize et al. (1987) have shown that parasitic diseases can affect the taste of meat.

Abdul-Aziz (2000) recorded a significant difference at $(\mathrm{P}<0.05)$ in live weight at slaughter and carcass qualities between the infected and control group of Awassi lambs, while in Bulgarian breed he found a significant difference $(\mathrm{P}<0.05)$ only in dressing percentage based on live weight and carcass weight after the chilling while the other carcass qualities were not statistically significant.

The present study revealed that the effect of subclinical infection with $H$. contortus was very slight on the ash percentage of meat in all areas (leg, ribs and fore shank) because the ash percentage is very small comparing with other composition of meat.

The moisture percentage in leg, ribs $(9,10,11)$ and fore shank of infected lambs was higher than the control group. This result me be due to the increasing of protein and fat percentage in control lambs group.

The result revealed that there was slight effect of subclinical infection with $H$. contortus on Karadi lambs.

\section{REFERENCES}

Abdul-Aziz, N.S. (2000): The effect of subclinical infection with $H$. contortus on carcass quality of Awassi and Belivin Bulgarian lambs. Zanco, 12: 5-14. 
Albers, G.A.A.; Lejamber, L.F.; Barker, J.S. and Piper, L.R. (1984): Production loss due to Haemonchus contortus infection in Merino weaners. Some preliminary results. Proc. Aust. Soc. Anim. Prod. 15: 647 (Helminth Abst. (1984), Vol. 53 (7) Abst. No. 2647).

Ali, A.A. (1981): The effected of subclinical infection with Haemonchus contortus on production parameters in sheep. Ph.D. thesis, university of Newcastle Upon Tyne.

Al-Jakhsi. N.S.A. (1986): Effect of H. contortus infection on some productive and physiological aspects of Awassi and Belivin Bulgarain breeds. M.Sc. Thesis, Coll. of Vet. Med. Baghdad University.

Al-Saqur, I.M.; Tarish, J.H.; Al-Abassy, S.N. and Kadhim, F.S. (1984):

Gastro-intestinal helminths of spring and autumn in Awassi lambs. Iraqi. J. Vet. Med., 8: 57-63.

Asghar, M.N. (1982): Interactions between host nutrition and the pathophysiology of gastrointestinal helminthiasis: a review M. V.

M. Thesis, University of Glasgow.

Association of Officail Analytical Chemists (A.O.A.C.) (1980): Official method of analysis. $13^{\text {th }}$ ed, assoc. of official analyt. Chem. Wasshington, D.C.

Bowman, D.D. and Lynn, R.C. (1999): Georgis' Parasitology for Veterinarians ( $7^{\text {th }}$ ed.), W. B. Saunders com. Philadelphia.

Coop, R.L. (1979): Feed intake and utilization by the parasitized ruminant. Int. Atomic Energy Agency, Advisory Group Meeting, 10-14 Sept., Cambridge, U.K.

Coop, R.L.; Graham, R.B.; Jackson, F.; Wright, S.E. and Angus, K.W. (1985): Effect of experimental Ostertagia circumcincta infection on the performance of grazing lambs. Res. Vet. Sci., 38: 282-287.

Donald, A.D. and Wallar, P.J. (1973): Gastro-intestinal nematode parasite population in ewes and lambs and the origin time course of larval availability in pasture. Int. J. Parasitol., 3: 219-133.

Garrize, C.A.; Gallinger, M.M.; Touraille, C.; Steffan, P.E.; Fiel, C.A.; Ambrustulo, R.R.; Bionddani, C.A.; Zamorano, M. and Bulman, G.M. (1987): Gastrointestinal parasitism and its effect on muscle, fat and bone composition of the carcass and organoleptic characteristic of meat. In: Proceedings MSD Agvet Symposium on Gastrointestinal Parasitism, August 19, pp. 56-68.

Ghazal, N.T. and Al-Saeegh, M.N. (1980): The sheep wool production. Books house for printing and publishing. Mosul University 
Gordon, H. McL. and Whitlock, H.V. (1939): A new technique for counting nematode egg in sheep faeces, J. Coun. Sci. Ind. Res. Australia, 12: 50-52.

Hartwig, N. (2000): Sheep health-fact sheet no. 8: Control of internal parasites of sheep. USDA, Iowa state university. (Cited by Watkins, A.D., M.Sc. Thesis, Louisiana State University, 2003).

Issa, W.H.; Altaif, K.I. and Al-Abassy, S.N. (1984): The seasonal distribution and prevalence of gastrointestinal helminths of sheep in Iraq. Iraqi. J. Vet. Med., 8: 65-76.

Kadhim, J.K. (1972): A survey of gastro-intestinal helminth parasites of sheep in Iraq. Trop. Anim. Hlth. Prod., 4: 109-12

Pralomkarn, W.; Pandey, V.S.; Ngampongsi, W.; Choldumrongkul, S.; Saithanoo, S.; Rattaanachon, L. and Verhulst, A. (1997): Genetic resistance of three genotypes of goats to experimental infection with Haemonchus contortus. Vet. Parasitol. 68 (1-2): 79-90.

Soulsby, E.J.L. (1982): Helminth, Arthropods and protozoa of domesticated animals. $7^{\text {th }}$ ed. Bailliere, Tinall and Cassell. P. 215252.

Sykes, A.R. and Coop, R.L. (1977): Intake and utilization of food by growing sheep with abomasal damage caused by daily dosing with Ostertagia circumcincta larvae. J. Agric. Sci. Camb., 88: 671.

Theodorides, V.V. (1964): A simple method for culture and recovery of larvae of intestinal nematodes of sheep. Vet. Rec., 76: 353-54.

Thomas, R.J. and Ali, D.A. (1983): The effect of Haemonchus contortus infection on the pregnant and lactating ewes. In. J. Parasitol., 13: 393-398.

Urquhart, G.M.; Armour, J.; Duncan, J.L.; Dunn, A.M. and Jennings, F.W. (1996): Textbook of Veterinary Parasitology. $2^{\text {nd }}$ ed., Blackwell Science Ltd. 